811.163.41'367.332

https://doi.org/10.18485/msc.2018.47.1.ch5

Милош М. КОВАЧЕВИЋ

Филолошки факултет Београд

Филолошко-уметнички факултет Крагујевац
Оригинални научни рад

Примљен: 10. 10. 2017.

Прихваћен: 27. 12. 2017.

\title{
ИНТЕРДЕПЕНДЕНЦИЈА ПЕРМУТАБИЛНИХ ФОРМИ ПРАВОГ И НЕПРАВОГ ОБЈЕКТА У СИНТАГМАМА С ГЛАГОЛИМА „НУДИТИ” И „СЛУЖИТИ”
}

\begin{abstract}
У раду се врши синтаксичко-семантичка анализа дворекцијских објекатских синтагми с пермутацијом типова објекта, и то синтагми с глаголима (по)нудити и (по)служити с двама беспредлошким објектима: акузативним (правим) и инструменталним (неправим), с могућношћу пермутације индиректнообјекатске форме (инструменталне) у директнообјекатску (акузативну), која интердепенденцијски подразумијева замјену директнообјекатске (акузативне) у индиректнообјекатску (али не инструменталну, него дативну, форму), као нпр.: (По)нудили/(по)служили су нас јелом и пићем // нам јело и пиће. Показује се који критеријуми предодређују синониман или блискозначан статус ових конкурентних синтагми.

Кључне ријечи: дворекцијске глаголске синтагме, интердепенденција, пермутација објеката, конверзија, унутарфункционална конверзија, глаголи (по)нудити и (по) служити.
\end{abstract}

Најприје је потребно указати на значење термина интердепенденција и пермутаиија, које овдје употребљавамо у значењима што им га је дао творац глосематике Луис Хјелмслев (1980: 32, 70). По Хјелмслеву је интердепенденција двострука импликација, или међуоднос два елемента у којем појава једног обавезно значи и појаву другог и обрнуто (као нпр. однос употребе предлога и облика локатива у српском језику, јер кад год употријебимо локативни предлог морамо употријебити и локативни облик супстантивне рије-

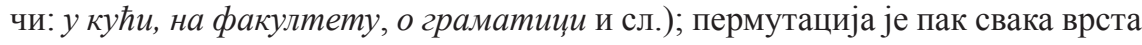
супституције (нпр. замјена позиција: моја мајка, мајка моја, или пак замјена неког облика ријечи другим, нпр.: пије воде/воду, или једне врсте ријечи другом, нпр.: плаво небо/ плаветнило неба и сл.). Док се интердепенденција може остварити и унутар дијела једне лексеме, нпр. у оквиру морфеме (нпр.

*mkovacevic31@gmail.com 
жен- $a$ ), дотле пермутација увијек подразумијева најмање дволексичку конструкцију (замјену најмање двије лексеме или алолексе).

Интердепенденција и пермутабилност нужне су карактеристике сваког типа конверзије: и а) творбене конверзије, која је морфемски необиљежен прелазак једне врсте ријечи у другу (нпр.: добро дијете - придјев, и добро учи - прилог), и б) лексичкосемантичке конверзије, која подразумијева реципрочан и симетричан однос двију лексема исте врсте ријечи унутар реченице (нпр.: Јован је Миланов гост / Милан је Јованов домаћин; Јован иде испред Милана / Милан иде иза Јована), и в) синтаксичкофункиионалне конверзије, која подразумијева међусобну супституентност двију јединица у различитим синтаксичким функцијама унутар реченице (нпр. замјену придјевског конгруентног атрибута прилошком адвербијалном одредбом начина (нпр.: Одиграли су одличну утакмииу/ Одиграли су одлично утакмииу; Добили су бесплатно учбенике / Добили су бесплатне уибенике) (О сва три типа конверзије в. у Ковачевић 2016 и тамо наведеној литератури).

Иако се са тим термином не доводи у везу, може се говорити и о унутарфункиионалној конверзији, тј. конверзији двају различитих морфолошких подтипова јединице у оквиру једне синтаксичке функције, као нпр. атрибута (супституентност конгруентног и неконгруентног атрибута, нпр.: ирноока дјевојка / дјевојка ирних очију, кошуља од свиле / свилена кошуља), или пак објеката (супституентност правог и неправог објекта, нпр: Заборавила је на mу обавезу /mу обавезу). Овај тип унутарфункционалне конверзије литература по правилу разматра у оквиру синонимије хомофункционалних језичких јединица.

У граматикама и научним радовима унутарфункционална објекатска конверзија готово безизузетно је разматрана у оквиру синтагми с једнорекцијски замјењивим елементом, нпр. замјеном правог неправим или неправог правим објектом. У литератури се ријетко и спомиње, а камоли да се шире говори о конверзији обају објеката унутар дворекцијске глаголске синтагме. А конверзија двообјекатске глаголске синтагме у српскоме језику може бити двоврсна: 1) да један од објеката мијења свој тип (ако је нпр. неправи трансформише се у прави), а да други од објеката мијења своју функцију (трансформише се не у форму другога објекта, него у форму прилошке одредбе или допуне на примјер), и 2) да се два објекта „врсно” пермутирају: прави се остварује у форми неправог, а неправи у форми правог, на примјер: Понудили су нам кафу / Понудили су нас кафом).

Први тип конверзије остварује се, како је то већ констатовала Ј. Московљевић Поповић, у комплексно рекцијским синтагмама с глаголима „uz koje je moguća tzv. lokativna alternacija. Ovi glagoli, koji mahom označavaju nanošenje supstance na neku površinu, ili smeštanje objekta u neki trodimenzionalni prostor, javljaju se sa dve dopune od kojih jedna uvek označava lokaciju, a druga supstancu ili entitet čija se pozicija u odnosu na datu lokaciju menja tokom realizacije aktivnosti označene glagolom. U svakoj od alternativnih konstrukcija po jedna od dopuna je aktualizovana u funkciji direktnog objekta, tj. kao NP u akuzativu bez predloga", док се "imenička fraza koja označava lokaciju realizuje 
[...] kao predloško-padežna konstrukcija $u / n a+N P_{a c c}$ odnosno kao predloško-pa-

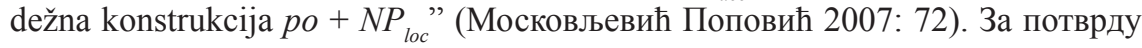
наводимо само неколико примера датих синтагми с глаголима посути, насуmи, мазати и намазати':

Посули су траву хемикалијама / Посули су по трави хемикалије; Насули су земљом рупу / Насули су земљу у рупу; Мазала је кожу хидратантном кремом / Мазала је хидратантну крему на кожу; Мајка нам је намазала хлеб машћу и алевом паприком / Мајка нам је намазала маст и алеву паприку на хлеб/по хлебу и сл.

Овај тип конверзије није предмет анализе овога нашега рада. Овдје ћемо анализирати само дворекцијске синтагме с глаголима нудити, понудити, служити и послужити с двама беспредлошким објектима: акузативним (правим) и инструменталним (неправим), с могућношћу пермутације индиректнообјекатске форме (инструменталне) у директнообјекатску (акузативну), која интердепенденцијски подразумијева замјену директнообјекатске (акузативне) у индиректнообјекатску (али не инструменталну, него дативну, форму). У питању су, дакле, синтагме с дворекцијским глаголима с пермутабилношћу правог и неправог објекта, тј. објекатске синтагме у којима обје објекатске лексеме подлијежу објекатској конверзији: лексема у неправом инструменталном објекту може се реализовати и у форми акузативног правог, што нужно значи да тада лексема у позицији акузативног правог мора прећи у форму дативног неправог објекта.

На овај тип бифункционалне објекатске конверзије, и то и с глаголом нудити и с глаголом служсити, најприје скреће пажњу једини српски рекцијски рјечник (Петровић/Дудић 1989: 57, 104), указујући на њихову синонимност управо навођењем синонимних допуна некога нечим // некоме нешто 2 ; што за глагол нудити потврђује и експланаторна парантетичка напомена у Речнику САНУ (2001: 65): „нудити. 1. а. (обично с допуном: некоме нешто, некога нечим)". Падежни оквир датих глагола чине, дакле, две беспредлошке објекатске форме, и то или: а) акузативна и инструментална (нпр. Нуде/Служе

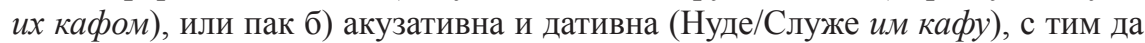
су те форме међусобно пермутабилне, при чему је пермутабилност интердепенденцијског типа, пошто замјена падежне форме једног од објеката нужно подразумијева и замјену падежне форме другог објекта. Конкретно речено, у двама наведеним моделима пермутабилност подразумијева обрнуту пер-

${ }^{1}$ J. Московљевић Поповић (2007: 73) издваја сљедеће глаголе уз које је могућа „ovakva vrsta lokativne alternacije": ,, doliti, filovati, izlepiti, mazati, iscrtati, ispisati, isprskati, nafilovati, naliti, namazati, naseliti, nasuti, natovariti, natrpati, natruniti, poprskati, posuti, preliti, premazati, puniti, zasejati..."

${ }_{2}^{2}$, „НДИТИ, несв. обав. компл. прел.

1. (послуживати шта коме)

a) А (ж)+ И (н) // Д (ж)+ А (н): некога нечим // некога нешто госта пићем // госту пиће" (Петровић/Дудић 1989: 57).

„СЛУЖИТИ

2. (нудити што коме, послуживати кога чиме)

$\mathrm{A}(\mathrm{H})+$ Д(ж): $\sim$ нешто некоме $\sim$ кајмак гостима

// И(н) + Д (ж): нечим некога крухом и сољу званице” (Петровић/Дудић 1989: 104). 
спективизацију правог и неправог објекта: прави објекат из једнога модела постаје неправи у другом, и обрнуто, с тим да у алтернацијски однос улазе акузативна и инструментална форма с једне стране, и акузативна и дативна форма с друге (уп.: Нуде/Служе их кафом $\rightarrow$ Нуде/Служе им кафу). Уз то, дату унутарфункционалну конверзију, прати као иманентна и имплицитна лексичка конверзија (нуде их кафом - прихватају кафу; служе их пићем - прихватају пиће), због чега ове глаголске синтагме Н. Арсенијевић (2012: 39-42) и сврстава у групу објекатских синтагми с „конверзним односом".

Од србистичких и/или сербокроатистичких граматика постојање овог типа глаголских синтагми с конверзним односом, с управним глаголима (по)нудити и (по)служсити, констатује граматика П. Мразовић и 3. Вукадиновић, гдје се каже да у оквиру глаголског модела с акузативним и дативним објектом „treba još ukazati na glagole (po)služiti i (po)nuditi koji u istom značenju mogu da se jave sa dopunom u akuzativu (biće) i instrumentalu (predmet koji se nudi)", као нпр.: Majka je deci (po)nudila/(po)služila kolače // Majka je decu (po)nudila/ (po)služila kolačima. (Мразовић/Вукадиновић 1990: 481).

Мимо наведених рјечничких и граматичких констатација ове синтагме - и то само акузативно-инструменталне - с оба глагола (и с глаголом нудити и с глаголом служити) биљежи М. Ивић, не спомињући могућност њихове пермутабилности у акузативно-дативне, него се једино задржавајући на семантичкој вриједности инструменталног објекта. За разлику од М. Ивић, међу акузативно-дативним објекатским синтагмама „транслокативног односа”, и то унутар категорије „конверзног односа” Н. Арсенијевић наводи и по један примјер за синтагму и с глаголом нудити и с глаголом послужити, не спомињући могућност пермутације датих синтагми у објекатске акузативно-инструменталне синтагме (Арсенијевић 2012: 40). Осим М. Ивић и Н. Арсенијевић, синтагме с овим глаголима, изван рјечничке и граматичке литературе, спомињу још једино J. Московљевић Поповић и И. Палић ${ }^{3}$, указујући на конкурентност акузативно-дативног и акузативно-инструменталног модела (Московљевић Поповић 2007: 75-76; Палић 2010: 53), с тим да J. Московљевић Поповић (2007: 75-76) сматра да је „moguće rotirati direktni i indirektni objekat" уз сљедећу "malu grupu glagola": даровати, исплатити, нудити, понудити, послужити, служити ...

Глаголи које наводи J. Московљевић Поповић, а њихов број није ни коначан, не подразумијевају исте типове лексема у позицији акузативног и инструменталног објекта, тако да засигурно синтагме са свим тим глаголима нису ни комуникативно ни структурно-семантички „конкурентне”. Зато ћемо се овдје задржати само на двообјекатским синтагмама с глаголима (по)нудити и (по)служити, као блискозначним и структурно изоморфним. Навешћемо већи број корпусних примјера за оба типа синтагми, и с глаголом

\footnotetext{
${ }^{3}$ Интересантно је да Д. Гортан Премк у својој монографији о акузативним синтагмама без предлога, иако има посебно (пот)поглавље „О акузативно-инструменталним паралелизмима” (Гортан Премк 1971: 58-61), међу синтагмама с тим паралелизмом уопште не спомиње синтагме с глаголима (по)нудити и (по)служити.
} 
(по)нудити, и с глаголом (по)служити, у обје структурне варијанте: и синтагме с акузативним и инструменталним, и синтагме с акузативним и дативним објектом, с тим да ћемо уз сваки примјер у загради са стрелицом давати и његову пермутабилну варијанту:

\section{(1) (ПО)НУДИТИ / (ПО)СЛУжИТИ + Ак (живо) + Ин (неживо):}

Често $u x$ нудите водом [ $\rightarrow$ Често им нудите воду]. (Блиц, 9. 5. 2010, 14); Нуде нас јелом [ $\rightarrow$ нам јело], а ни за себе немају. (Политика, 30. 4. - 2. 5. 2015, 16); Ученицима који су му се свиђали давао је решене контролне задатке, поклањао петице и нуткао их поклонима [ $\rightarrow$ им поклоне]. (Курир, 14. 5. 2010, 10); Бећа нуди ракијом. [ $\rightarrow$ Бећу нуди ракију]. (Р. Вучковић, 139); Пошто је посетиоца ... понудила кафом и чајем [ $\rightarrow$ посетиоиу понудила кафу и чај], Хаџи-Пешићева је казала... (Политика, 19. 7. 2015, 26); ...нуде ли сапутнике кобасииом и јабукама [ $\rightarrow$ сапутницима кобасице и јабуке ]. (Политика, 18. 10. 2015, 25: Момо Капор);- Послужите се и медом. Отац ми пре неки дан донео - нутка [нас] Бисера медом, кафом и иигаретама [ $\rightarrow$ нутка нам Бисера мед, кафу и ицгарете ]. (Политика, 25. 7. 2016, 7); Увек те нуде нечим, пићем, храном [ $\rightarrow$ Увек ти нуде нешто, пиће, храну]. (Политика, 20. 8. 2016, 25); ... а он ме нутка ракијом [ $\rightarrow$ ми нутка ракију]. (Курир, 18. 7. 2009, 3: Брана Црнчевић); Понудио ме је пићем [ $\rightarrow$ Понудио ми је пиће]. (Вечерње новости, 13. 3. 2010, 33: Момо Капор); Бакице су у ношњама сачекале Кусту и његове музичаре на железничкој станици, нудећи их вотком, чајем и колачима [ $\rightarrow$ им вотку, чај и колаче]. (Вечерње новости, 29. 5. 2012, 37); Ње више нам у кући да га понуди ракијом [ $\rightarrow$ да му понуди ракију]. (Д. Ћосић, 181); До краја летовања ... нудио нас је најбољим Ђаконијама [ $\rightarrow \ldots$ нудио нам је најбоље Ђаконије]. (Политика, 25. 8. 2017, 25); Херцигоња ме, наравно, није понудио цигаретом [ $\rightarrow$ мu, наравно, није понудио цигарету] јер је он пушио - лулу! (Политика, 9. 1. 2010, КУН, 7); Нуди га циигаретом [ $\rightarrow$ му циигарету]. (Данас, 31. 12.2012 -2. 1. 2013, 7) итд.

Ako ste sanjali kako služite hranom druge osobe [ $\rightarrow$ hranu drugim osobama ], taj san ukazuje na neko neplanirano veselje koje će vas jako obradovati (horoskopzadanas.com/sanovnik); Goste koji su dolazili poslije vjenčanja posluživala sam večerom $[\rightarrow$ Gostima $\ldots$ posluživala sam večeru] (forum.klix.ba/sta-pravite-kada-vam-se-najave-gosti-p6241863); Ugostitelj je dužan da posluži gosta jelom i pićem $[\rightarrow$ gostu jelo i piće $]$ koje je po jelovniku ili karti pića naručeno. (www.zlatibor.org.rs/sites/default/); Želite da popijete i poslužite prijatelje ili kolege espresom $[\rightarrow$ prijateljima ili kolegama espreso] „kao u kafiću”? (www.coffeefair.rs/ tag/espreso/) итд.

\section{(2) (ПО)НУДИТИ / (ПО)СЛУжИТИ + Ак (неживо) + Д (живо):}

Нуде нам поморание [ $\rightarrow$ нас помораниама]. (Данас, 2-3. 9. 2017, додатак „Недеља”, $\mathrm{IX);} \mathrm{Између} \mathrm{осталог} \mathrm{нудио} \mathrm{им} \mathrm{је} \mathrm{кокаин}[\rightarrow \ldots$ нудио $и x$ је кокаином]. (Арсенијевић 2012, 40: Вечерње новости); -Ti si nam nudio hljeb i meso? [ $\rightarrow$ Ti si nas nudio hljebom i mesom?]. (Палић 2010, 53: Derviš Sušić); Izvinite, gospođice, mogu li vam ponuditi jedno piće? [ $\rightarrow$...mogu li vas ponuditi jednim pićem?] (www.statusi.rs/izvinite-gospodice-mogu-li-vam-ponuditi...); Nije važno da li nudite hranu vašoj bebi $[\rightarrow$ hranom vašu bebu] pre ili između dva uobičajena obroka (http://www.najboljamamanasvetu.com/2010/08/); Pazite kada vam neka žena ponudi piće [ $\rightarrow$ kada vas neka žena ponudi pićem ] (opusteno.rs > Zabava > Zanimljivosti); Треба ии свакодневно нудити разноврсну храну [ $\rightarrow$ Треба $и x$ свакодневно нудити разноврсном храном] (www.vodiczaroditelje.rs/) итд.

Затим преко даске пребаци бели убрус и послужи капетану Onуjићу лаку вечеру $[\rightarrow$ капетана Опујића лаком вечером]. (Арсенијевић 2012, 40: Милорад Павић); Nikako i nikada ne služiti alkoholno piće maloletnim licima $[\rightarrow$ alkoholnim pićem maloletna lica $]$ (www. ugostiteljstvo.com/poslovni-saveti/26/); Kako poslužiti vino gostima? [ $\rightarrow$ vinom goste] (www. ugostiteljstvo.com/edukacija/65/); Ako ste videli sebe kao osobu koja služi kolače nekome $[\rightarrow$ kolačima nekoga], to je znak da vam u narednom periodu slede uspeh (https://sanovniktumac. com/); Kako da hranu poslužite gostima [ $\rightarrow$ da hranom poslužite goste ] na kreativan način (bride.wannabemagazine.com/planiranje-і...) итд. 
Синтагме с глаголима (по)нудити и (по)служсти реализују се са двама објектима, од којих је један анимативни (+живо), а други неанимативни (- живо). Објекат за живо означава човјека, док се именицом за неживо именује или храна, или пиће, или дуван (цигарете), или дрога (наркотици). Мимо круга именица за ЈЕЛО, ПИЋЕ, ДУВАЬЕЬЕ и ДРОГИРАЬЕ не остварује се конверзивни (пермутабилни) модел двообјекатске синтагме с инструменталом: (по)нудити/ (по)служити + Ак (живо) + Ин (неживо). На ту конкурентност модела Ак (живо) + Ин (неживо) и Ак (неживо) + Д (живо) упућују и рјечничка значења њихових управних глагола, и то не конкурентност цијелог значења, него само једног од значења датих глагола (в. Речник САНУ 2001: 65; Речник MC 1971: 753). На основу мјеста које дато значење заузима у структури семантеме датога глагола, јасно је да је глаголима нудити и понудити ово примарно значење, док двама осталим конкурентним глаголима (служити и послужсти) то није примарно, него изведено, друго или треће, значење унутар семантеме.

Иако су глаголи са пермутабилним објекатским допунама Ак (живо) + Ин (неживо) и Ак (неживо) + Д (живо) међусобно конкурентни, они нису потпуно синонимни. Синонимност ових дворекцијских глаголских синтагми зависи од више прагматичко-семантичких чинилаца, а прије свега од тога да ли је при реализацији датих синтагми актуелизована семантичка компонента: а) гошћења / чашћавања, б) продавања / купопродаје, в) наруџбе, в) типа локализатора.

Синтагме с падежним оквиром Ак (живо) + Ин (неживо) по правилу су обиљежене семантичком компонентом „гошћења”, с тим да је „угошћивач” домаћин, а „угошћени” - гост. Овакав статус „даваоца” и „примаоца” у датим синтагмама искључује као плеонастично навођење податка о „бесплатности”, тј. неплаћању, уп:: (По)нудио/(по)служио/ нас је ручком, *који је био бесплатан / који није требало да платимо. Готово да се правилом може сматрати да наведени глаголи с падежним оквиром Ак (живо) + Ин (неживо) подразумијевају значење чашћавања или угошћавања. То, међутим, није случај и са конкурентим пермутабилним моделом, у коме падежни оквир чине Ак (неживо) + Д (живо). Тај је модел неутралан у погледу компоненте „чашћавања/гошћења” без обзира на статус „даваоца” и „примаоца” понуде, што показују и сљедећи примјери: (По)нудио/(по)служио/ нам је ракију да се почастимо / да платимо / да купимо. Разлику између та два модела најочигледније показује навођење семантички (ин)компатибилних циљних клауза: Нудио нам је ракију (=1. да се почастимо, 2. да се послужимо; 3. да купимо, али: Нудио нас је ракијом (=1. да се почастимо, 3. да се послужимо; 4. *да купимо). Моделу с инструменталом по правилу је, дакле, инкомпатибилна компонента „купопродаје”.

Четири се наведена глагола не понашају једнако у контекстима који подразумијевају специфичне локализаторе. Ако је локализатор домаћинова кућа, онда се подразумијева компонента чашћавања или угошћавања, која истовремено искључује компоненту „продавања”. Ако је пак локализатор било који тип продајног објекта (изван угоститељског), онда се компонента 
„чашћавања” искључује. Друкчије речено, кад год давалац и прималац имају статус продавца и муштерије (купца) уз глаголе нудити/понудити искључује се значење „чашћавања", а као примарно намеће значење „купопродаје”, уп.: Продаваи/понудилаи је купиу (муштерији) нудио месо/воће повољно / бесплатно / за мале паре, али не: *Продаваи/понудилаи је купца (муштерију) нудио месом/воћем повољно/бесплатно/за мале паре. У готово свим ситуацијама које не подразумијевају компоненту чашћавања, истовремено имплицирајући као иманентну компоненту „бесплатности”, глаголи служити и послужити нису значењски конкурентни глаголима нудити и понудити, уп. нпр.: Продавац је купцу (по)нудио рибу и салату / *Продавац је купцу (по)служио рибу и салату.

Глагол (по)служити готово да као иманентну подразумијева компоненту „чашћавања" уз све локализаторе мимо чисто продајних објеката (продавница, тржница, пијаца, трговина, радња...), као нпр.: У авиону / у канщеларији / на састанку (по)служе нас кафом и киселом водом / нам кафу и киселу воду. Осим уз „домаћински дом”, и уз наведене локализаторе ови су глаголи, како се види, конкурентни глаголима нудити и понудити у датим синтагмама.

Употребе двообјекатских конкурентних синтагми са сва четири наведена глагола - нудити/понудити и служити/послужити - семантички је најсложенија и „најзамршенија” у контекстима с угоститељским објектом као локализатором. Најприје, од четири наведена глагола, само глаголи $н y$ дити и понудити могу и у угоститељском објекту као мјесту „обједовања” имати значење „чашћавања”, када неко некога чашћава плаћајући му јело или nиће. Таква се употреба, у значењу „чашћавања у кафани” за глаголе служити и послужсити искључује, као нпр.:

(По)нудили /*(По)служили су нас кафом и ракијом /нам кафу и ракију у кафани $[\rightarrow$ Понудили су да нам плате пиће и јело у кафани / да нас часте, плаћајући кафу и ракију]

У контекстима који подразумијевају угоститељски објекат као локализатор, остварује се и низ других специфичних значења наведених глагола, при чему су у неким од тих значења дати глаголи конкурентни, а у неким употребно инкомпатибилни, што на најбољи начин показују сљедећи примјери:

a) Конобар нам је (по)нудио - да изаберемо/наручимо - пиво, ильиву или лозу за пиће, а јагњетину или роштиљ за јело.

б) *Конобар нас је (по)нудио - да изаберемо/наручимо - пивом, иљьивом или лозом за пиће, а јагњетином или роштиљем за јело.

в) *Конобар нам је (по)служио - да изаберемо/наручимо - пиво, шљьиу или лозу за пиће, а јагъетину или роштиљ за јело // пивом, шљивом или лозом за пиће, а јагњетином или роштиљем за јело.

\footnotetext{
${ }^{4}$ Што потврђује и сљедећи корпусни примјер: Велики број излагача нуди [купичима] разне врсте ракија, цемова, воћа (Вечерње новости, 27. 8. 2017, 33: поднаслов).

${ }^{5}$ На то упућује и распрострањен и врло уобичајен израз којем је то значење иманентно, а то је израз: „[по]служи(те) се! разг. уобичајена друштвена форма кад се коме нуди јело или пиће” (Речник МС 1973: 869).
} 
г) Конобар нас је (по)нудио/(по)служио пивом и јагњетином које смо наручили.

д) Конобар нам је (по)служио пиво и јагњетину које смо наручили/ изабрали.

ђ) *Конобар нам је (по)нудио пиво и јагњетину које смо наручили/ изабрали.

На основу наведених примјера могу се извести неколика битна закључка.

У контекстима који подразумијевају угоститељски објекат као локализатор а када угоститељски радник госту „предлаже избор јела и пића” (а) могућа је употреба само глагола (по)нудити и то с падежним оквиром Ак (неживо) + Д (живо), док се искључује (б) употреба падежног оквира Ак (живо) + Ин (неживо), као и употреба глагола (по)служити с било којим од наведених падежних оквира (в).

У реализацији „наруџбине” (доношењу/сервирању нарученог јела и пића) у угоститељском објекту као локализатору синонимно се (г) употребљавају синтагме и с глаголом (по)нудити и с глаголом (по)служити с падежним оквиром Ак (живо) + Ин (неживо), с тим да се такво значење може изразити и моделом Ак (неживо) + Д (живо) уз глагол (по)служити (д), док се у таквим контекстима, с тим падежним оквиром, искључује употреба глагола (по)нудити (ђ), што значи да је глаголу понудити инкомпатибилна компонента „сервирања” кад се он остварује у моделу с акузативом и дативом (што је и логично јер понуда значи нереализацију, а „сервирање” подразумијева реализацију као резултат понуде).

Да закључимо. У раду су анализиране дворекцијске синтагме с глаголима (по)нудити и (по)служити с двама беспредлошким објектима у српском језику: акузативним (правим) и инструменталним (неправим), с могућношћу пермутације индиректнообјекатске форме (инструменталне) у директнообјекатску (акузативну), која интердепенденцијски подразумијева замјену директнообјекатске (акузативне) у индиректнообјекатску (али не инструменталну, него дативну, форму), као нпр.: (По)нудили / (по)служили су нас јелом и пићем // нам јело и пиће.

Глаголске синтагме с глаголима (по)нудити и (по)служити реализују се са двама објектима, од којих је један анимативни (+ живо), а други неанимативни (- живо). Објекат за живо увијек подразумијева човјека, док се именицом за неживо именује или храна, или пиће, или дуван (цигарете), или дрога (наркотици). И само у том случају синтагме с наведеним глаголима су синонимне, или боље рећи - блискозначне. Синонимност и/или блискозначност ових дворекцијских глаголских синтагми зависи од више прагматичко-семантичких чинилаца, а прије свега од тога да ли је при реализацији датих синтагми актуелизована семантичка компонента или није: а) гошћења/чашћавања, б) продавања /купопродаје, в) наруџбе, в) типа локализатора. 


\section{ИЗВОРИ}

а) књижевноумјетничка дјела:

Р. Вучковић - Радован Вучковић, Тумарањ $а$, Београд: Свет књиге, 2005. Д. Ћосић - Добрица Ћосић, Корени, Београд: Laguna, 2016.

\section{б) новине:}

Блиц - Blic, dnevne novine iz Beograda Вечерње новости - Вечерње новости, дневне новине из Београда Данас - Danas, dnevne novine iz Beograda Курир - Kurir, dnevne novine iz Beograda НИН - НИН, недељне информативне новине из Београда Политика - Политика, дневне новине из Београда

в) интернетски сајтови (интернет адресе дате уз примјере) (npucmyn: 14. 3. 2017).

\section{ЛИТЕРАТУРА}

Арсенијевић 2007: Nada Arsenijević, Tranzitivnost i padeži objekta u srpskom jeziku, Зборник Матице српске за славистику, 71-72, 377-390.

Арсенијевић 2012: Нада Арсенијевић, Падежи правог објекта у стандардном српском језику, Нови Сад: Филозофски факултет Нови Сад.

Гортан Премк 1971: Даринка Гортан-Премк, Акузативне синтагме без предлога у српскохрватском језику, Београд: Институт за српскохрватски језик.

Ивић 1954: Милка Ивић, Значења српскохрватског инструментала и њихов развој, Београд: Научна књига.

Јакобссон 2008: Roman Jakobson, O jeziku, s engleskog preveo Damjan Lalović, Zagreb: Disput.

Ковачевић 2016: Милош Ковачевић, Реченице с конверзијом прилошке адвербијалне допуне или одредбе и придјевског атрибута, у: Jezik, književnost, značenje. Jezička istraživanja, Niš: Filozofski fakultet, 389-408.

Московљевић Поповић 2007: Jasmina Moskovljević Popović, Ogledi o glagolskoj potkategorizaciji, Beograd: Čigoja štampa.

Мразовић/Вукадиновић 1990: Pavica Mrazović, Zora Vukadinović, Gramatika srpskohrvatskog jezika za strance, Sremski Karlovci: Izdavačka knjižarnica Zorana Stojanovića, Novi Sad: Dobra vest.

Палић 2010: Ismail Palić, Dativ u bosanskome jeziku, Sarajevo: Bookline. 
Петровић/Дудић 1989: Владислава Петровић, Коста Дудић, Речник глагола са граматичким и лексичким допунама, Београд - Нови Сад: Завод за уџбенике и наставна средства, Завод за издавање уџбеника.

Речник МС 1971/1973: Речник српскохраватскога књижевног језика, књига четврта (1971), књига пета (1973), Нови Сад: Матица српска.

Речник САНУ 2001: Речник српскохрватског књижевног и народног језика, књ. 16, Београд: Институт за српски језик.

Хјелмслев 1980: Luis Hjelmslev, Prolegomena teoriji jezika, prevod s njemačkog Ante Stamać, Zagreb: GZH.

Miloš M. Kovačević

\author{
INTERDEPENDENCE BETWEEN INTERCHANGEABLE FORMS OF \\ DIRECT AND INDIRECT OBJECT IN VERB PHRASES CONSISTING \\ OF VERBS 'NUDITI' AND 'SLUŽITI'
}

\title{
Summary
}

This paper analyses ditransitive phrases with verbs like (po)nuditi (offer) and (po)služiti (serve) which bind two non-prepositional objects in Serbian language: one in the accusative case (direct object) and the latter in the 'instrumental' case (indirect object), with the possibility of alternation of indirect object ('instrumental' case form) into different form of indirect object (not in the instrumental case form, but - 'dative' case) in clauses such as: (Po)nudili/ (Po)služili su nas jelom i pićem// nam jelo i pice (in English: They offered us food and drinks// They offered food and drinks to us; We were served with food and drinks//They served food and drinks to us.)

Verb phrases consisting of verbs (po)nuditi (offer) and (po)služiti (serve) bind two objects, one of which is animate (human) and the latter non-animate (non-human). The animate object always refers to a human being, whereas the inanimate object refers to food or drinks, tobacco (cigarettes) or drugs (narcotics). Only when such criteria are met, phrases with above-mentioned verbs are synonymous, or better to say - of nearly the same meaning. Synonymy and/or similarity in meaning of these ditransitive verb phrases depends on plenty pragmatic and semantic factors, most of all on the fact whether the realization of these phrases includes the actualization of a particular semantic component: a) treating/ paying for somebody, b) selling / trading, c) ordering, d) type of complement (denoting place).

Key words: ditransitive verb phrases, interdependence, object permutation, conversion, conversion within function, verbs - (po)nuditi and (po)služiti. 